\title{
Private Sector Investments and Unemployment in Nigeria (1986-2016)
}

\author{
Ndugbu M. O. Ph.D Osuka B. O. Ph.D Duruechi Anthony H. \\ Department of Banking and Finance, Faculty of Management Sciences \\ Imo State University, Owerri, Imo State, Nigeria
}

\begin{abstract}
This research work examined private sector investments and unemployment in Nigeria. The period covered by the study is from $1986-2016$. The study aimed at identifying the impact of private sector investments on unemployment level in Nigeria. Times series data on Private Domestic Investment (PDI), Foreign Direct Investment (FDI), Foreign Portfolio Investment (FPI) and Unemployment rate were collected from secondary sources via the Central Bank of Nigeria Statistical Bulletin and World Bank Development Indicators. The Johansen co-integration, analysis, Vector Error Correction (VECM) and Pairwise Granger causality analysis were employed in the data analysis. The Johansen cointegration result indicated the existence of long-run relationship between private sector investment variables and unemployment rate in Nigeria. In the same vein, the Vector Error Correction Model (ECM) estimate equation is properly signed with a negative coefficient of -0.006644 but with an insignificant t-statistic probability value of 0.7376 at $5 \%$ significance level. The insignificant t-statistic implies that private sector investments do not granger cause unemployment rate in the long-run. However, a significant but negative relationship was found between past unemployment rate and private domestic investment lagged one period and unemployment rate in Nigeria. The study therefore recommended that sustainable policies that will ensure and encourage growth of private sector investments should be vigorously pursued by stakeholders in the industry. These policies could come in form of access to cheap funds (through reduced interest rates or cost of funds), subsidization of inputs in the production process, tax waivers or newly established firms among other policy initiatives.
\end{abstract}

Keywords: Private Sector, Investments, unemployment rate.

DOI: $10.7176 /$ RJFA/10-14-07

Publication date:July $31^{\text {st }} 2019$

\section{Introduction}

Economic and financial literature has shown that investment is the life-wire of every economy as it propels societal growth and development. It is in recognition of this fact that government of nations whether underdeveloped, developing or developed embark on investment friendly policies geared towards the attraction of investments into their economy. According to Bahar (2003), the increasing pace of globalization and technological developments made investment re-emerge as a key concern in economic growth. In the same vein, it is worthy of note that the world economy has undergone rapid changes in recent times and developing countries like Nigeria no doubt have made moves to align with these changes in diverse ways which gave rise to different outcomes. Among these outcomes is the rising emphasis on private sector investments.

Private Sector investments are investments made by private individuals or corporate individuals (local or foreign). In this sector, activities are under the control and direction of non-governmental unit (private or corporate individuals). In other words, the private sector encompasses all for-profit businesses that are not owned or operated by the government. The private sector investment promotes efficient growth and development through job and income creation. Thus, Tony (2016) asserted that in framing the set of goals, efforts should be made on tackling unemployment and job creation on a massive scale, and on dramatically improving access to electricity. These goals he noted, are both critical to lives and quality of live, and cannot be accomplished without collaboration with the private sector. In addition to the merit of private sector investments, it brings about social and political benefits by engaging people more actively in the production and decision making processes and tax bases created by private sector development can be directed to tackling social and environmental challenges (Bahar, 2003).

It was in recognition of the role played by the private sector through its investment activities that most African countries like Nigeria in the 1980s introduced major economic reforms that saw to the gradual withdrawal of government from ownership of enterprises in order to encourage private sector participation. In view of this, Agbadu (2007) noted that no country should ever rest on her own and expect fortune seeking private investors to grow her economy for her. Furthermore, it is up to the recipient economy to "exploit" the private investors through the judicious use of macro-economic policies deliberately designed to take advantage of the available private investment for the national benefits. The 1986 Structural Adjustment Programme (SAP) was introduced with the aim of encouraging private sector participation (among other objectives) whose role in the facilitation of economic growth is sine qua non for economic growth and development. Prior to this period, the Nigerian government pursued state led economic development policies that prompted government to create large-state owned enterprises 
and large public administrations to manage them while the private sectors were marginalized. Despite the protection from competition, these state owned enterprises failed to achieve the purpose for which they were established. They failed to innovate, relied on obsolete or inappropriate technologies, depended more on import for their inputs, exports were on the decline etc, the resultant effect been stagnation in economic development. According to Clem and Alajekwu (2016), the oil boom of the 1970s in Nigeria, among other factors gave impetus to a public sector-led government strategy. Public sector dominance was also prevalent in order to give government an increasing measure of control over its own resources, the dwindling revenue of government as a result of economic crisis of the 1980 s coupled with the dissatisfaction with the performance of the public sector compelled Nigeria into structural reforms.

According to Udo (2016), in recent years, private investment has been accorded renewed emphasis and importance "as the engine of growth and development". The crucial role of private investment in sustainable economic growth is also evidenced by data indicating high growth rate of economies with dominant private sector. Supporting this, Aminu and Mustapha (2014) observed that experiences of developed economies in relation to the role played by the private sector buttresses the fact that the importance of private sector cannot be overemphasized especially among developing countries. There is no gainsaying the fact that private sector investment engenders employment, efficiency in resource use/allocation, innovations, linkages with other sectors, competition, impacts on the quality of life, income generation, health, education etc which positively transform the economic fortunes of a nation and her citizenry leading to economic growth and development.

In Nigeria, private sector investments constitute a significant segment of the economy. Given the merits of the private sector and the downward trend/shift in public sector investments, private sector investment has been on the rise. Despite structural reforms and increase in private sector investment, Nigeria is still bedeviled with the economic malady of high and continuous rise in the rate of unemployment amongst other economic challenges. According to Imoisi, Abuo and Sogules (2015), the planned withdrawal of the government from the investment scene, leaving it to the private sector to play its function has not been too promising for the nation. For instance, private sector investment in the country rose from N8.6 billion in 1981 to $\$ 508.30$ billion in 2000 . This has continued to assume an upward trend such that in the first and last quarter of 2015 it rose to $\$ 13,357.10$ billion and $\$ 13,086.20$ billion respectively, (CBN 2015).

Unfortunately, rising private sector investment has not translated to meaningful reduction in the level of unemployment rate in Nigeria. This macroeconomic indicator (unemployment rate) which has overtime shown a gloomy picture has been on the increase. For instance, unemployment rate rose from $1.8 \%$ in 1995 to $12.3 \%$ in $2006,14.9 \%$ in $2008,19.7 \%$ in $2009,21.4 \%$ in 2010 , and $23.9 \%$ in 2011 . According to NBS (2012) as reported in Oni, Imolehin, Adelowo and Adejumo (2014) in 2012, Nigeria had unemployment rate of $21.35 \%$ broken down into $17.1 \%$ in the rural areas and $25.6 \%$ in urban. In 2016 alone, the unemployment rate rose from $12.1 \%$ in the first quarter, $13.3 \%$ in the second quarter and 13.9\% in the third quarter (NBS, 2011, 2016, World Bank 2017). The rapid growth in private sector has not translated into meaningful reduction in unemployment rate as the latter has continued to rise. The question that readily calls to mind is; what is then the impact of private sector investment on unemployment level in Nigeria?

Similarly, amongst the several studies on private sector investments in Nigeria, those that empirically investigated the relationship between private sector investment and unemployment rate are few. It is on the basis of these identified problems that this research is undertaken.

The period covered in the study ranges from 1986 - 2016. In this regard, private sector investments were disaggregated into Private Domestic Investment, Foreign Direct Investment and Foreign Portfolio Investment. Unemployment level is measured by Unemployment rate. The researchers limited the study to the unemployment rate among other measures of economic development.

\subsection{Review of Related Literature}

\subsection{Conceptual Review of Private Sector Investments}

Every economy is structured into the public and private sectors. Unlike the public sector, the private sector refers to that part of the economy that is in private hands and whose activities are under the control and direction of individuals or corporate individuals. In the private sector, private and corporate individuals own and control the means and factors of production. Conceptually, private sector investments are known as private investment. It is a form of investment that is profit oriented or profit elastic. Here, investors (individuals and corporate Individuals) are motivated and influenced by marginal efficiency of capital that is profit expectations and the rate of interest. Private sector investment (foreign or local) could be in form of private domestic investments and foreign private investment (foreign direct investment and foreign portfolio investment). Foreign Direct Investment, FDI for short entails investment from one country into another, normally by companies rather than government. It involves establishing operations or acquiring tangible assets, including stakes in businesses in other countries, while foreign portfolio investment involves the purchase of one country's securities by nationals of another country.

Udo (2016) observed that private investment is generally conceptualized in terms of physical capital 
formation. He noted that private investment in physical capital, usually are undertaken by firms and individuals to accumulate, overtime, real capital goods, which yield a future flow of goods and services. The real capital goods, according to Soludo (1998) is classified into business fixed capital goods like new machinery and equipment, new factories and offices, other durable goods, investing in new techniques and product with the aim of improving the quality and quantity of firm's output; and working capital such as cash, stock of raw materials and inventories. The private sector is also described by other names like capitalism, free enterprises system, the voluntary exchange economy, the market system and the profit system (Ademu, 2006). The role of the sector in propelling economic growth and development via employment and income generation amidst other potentials underscores the overwhelming emphasis and importance accorded private sector investment.

Unemployment on the other hand is far more complex than it is generally understood to mean "people do not have a job". The International Labour Organisation (ILO) in 1982 stated however that one can only be called an "unemployed" if he /she is: without work - that means he/she was not in paid employment or self employment during a particular reference period; "currently available for work" - that means he/she was ready for a paid employment or self employment during the reference period; and "seeking work" - that means he/she had taken specific steps in a specified recent period to seek paid employment or self-employment. Thus, according to the resolution concerning statistics of work, employment and labour underutilization adopted in 2013 by the $19^{\text {th }}$ International Conference of Labour Statistician (ICLS), the standard definition of unemployment refers to "all those persons of working age who are without work and currently available for work. Future starters, that is, persons who did not look for work but have a future labour market stake (made arrangements for a future job start) are also counted as unemployed.

In many national contexts, there may be persons not currently in the labour market who want to work but do not actively seek work because they view job opportunities as limited, or because they have restricted labour mobility, face discrimination or structural, social or cultural barriers. According to Elsby, Hobijn and Sahin (2013), the exclusion of such people is a criterion that will affect the count of both women and men although women may have a higher probability of being excluded from the count of unemployed because they suffer more from social barriers overall that impede them from meeting this criterion. Another factor leading to the exclusion from the unemployment count concerns the criterion that workers be available for work during the short reference period. A short availability period tends to exclude those who would need to make personal arrangements before starting work, such as for care of children or oderly relatives or other household affairs.

Accordingly, unemployment is a macroeconomic indicator that paints a picture on the state of the economy. However, the rate of unemployment is usually used to capture the number of people that are unemployed in a country. By definition, unemployment rate is defined mathematically as the ratio resulting from dividing the total number of unemployed (for a country or a specific group of workers) by the corresponding labour force, which itself is the sum of the total persons employed and unemployed in the group (Ernst and Rani, 2011). It should be stated that it is the labour force that serves as the base for this statistics, not the total population. Thus, Loungani (2010) stated that the overall unemployment rate for a country is a widely used measure of its utilized labour supply. If employment is taken as the desired situation for people in the labour force, unemployment becomes the undesirable situation.

Existing literature has shown that private sector investment has the capacity to reduce the unemployment rate. According to Udo (2016), this is the reason why private investment has been accorded renewed emphasis and important place "as the engine of growth and development". According to National Bureau of Statistics as reported by Trading Economics.com between 2006-2017, the unemployment rate in Nigeria increased to $14.2 \%$ in the last quarter of 2016 from $10.4 \%$ a year earlier. It is the highest jobless rate since 2009 as the number of unemployed went up by 3.5 million to 11.549 million while employment rose at a slower 680.8 thousand to 69.6 million. The labour force increased by 4.194 million to 81.151 million and those detached from it declines by 625.7 thousand to 27.439 million. The unemployment rate was higher for persons between $15-24$ years old $(25.2 \%)$, women $(16.3 \%)$ and in rural areas $(25.8 \%)$. In the previous quarter, the jobless rate was $13.9 \%$. Unemployment rate in Nigeria averaged $9.7 \%$ from 2006 until 2016, reaching an all time high of $19.70 \%$ in the fourth quarter of 2016. In Nigeria, the rate of unemployment has increased during the last few years, due to the fallout from economic challenges. Some of the causes of unemployment are high and rapid population growth, unstable and corrupt political environment, lack of skills, epileptic power supply, poor quality of education or lack of quality education, lack of infrastructure, negligence of agriculture and other natural resources, recession etc. These pose adverse effects on the society and the economy at large such as reduction in national output, increase in rural urban migration, poverty, increase in dependency and crimes (Udo, 2016). There is no doubt that one of the major ways these could be addressed is for the government to be productive through investments, creation of industrial friendly environment, and reformation of the education system etc.

\subsection{Theoretical Framework}

The theoretical foundation of this research relied upon the classical theory which posits that an economy shall be 
at full employment because at a wage pay, the demand for labour shall equal the supply. However, if there is an increase in labour supply, the wage pay would decrease and as more people would be employed. In the same vein, if there is a shortage of labour, the wage pay would increase thus eliminating the shortage. Therefore, in the classical view, voluntary unemployment would not exist if market forces are allowed to operate without restrictions. In this case, unemployment can only occur if there are interventions by government or any group in market mechanisms or forces of labour. This in other words means that market forces are efficient and reliable means of addressing the problem of unemployment.

Globally, the concept of market forces or mechanism can be applied to analyse private sector investments. Here, the forces of demand and supply are allowed to operate without interventions and used in resolving unemployment situations especially in developing countries. According to Aminu and Mustapha (2014), a large part of the economically active population of these countries finds an income generating source in economic activities outside the formal or modern sector of the economy.

Some economies are often referred to as mixed economies. According to Udo .(2016), a mixed economy connotes a framework in which allocative mechanism in respect of what is to be saved, invested, produced and at what price, is left to the forces of the market and not to any government or its agency. He further noted that in a mixed economy, the private sector should play a leading role while the public sector provides the enabling economic environment. In this regard, public sector participation in investment activities is reduced while private sector growth and/or investments are encouraged in view of their perceived role in national development and growth. The literature is replete with evidences that private sector investment in many developing countries is more directly related to economic growth than public sector investment, (khan and Reinhart, 1990).

\subsection{Empirical Review}

Empirical studies on the impact of private sector investments on economic growth in Nigeria abounds though not adequate in number. Similarly, there is a dearth of empirical literature on the direction of relationship or causality between private sector investment and unemployment level in Nigeria. Few of the empirical works concentrated on say a component of private sector investment or private sector investment viz-a-viz economic growth with little or no emphasis on the unemployment level in Nigeria. This gap formed the motivation for this study.

Haruna, Saifullahi and Mukhtar (2013) examined the relationship between financial sector development and unemployment in Nigeria spanning the period 1980 to 2011 using the Auto Regressive Distributed Lag (ARDL) Bound Test technique for the estimation of long-run (co-integration) relationship. Financial sector development were represented by such proxies as Credit to the private sector (CPC), Broad Money Supply $\left(\mathrm{M}_{2}\right)$, ratio of money supply to GDP ( $\left.\mathrm{M}_{2} / \mathrm{GDP}\right)$, Rural Bank Branch Deposit mobilized (rudepo) and formal loan allocated to the rural dwellers by rural bank branches (reloan). The result of the research revealed the existence of short run and long run relationship between financial sector development and unemployment level in Nigeria.

Salami and Oyewale (2013) examined the impact of foreign direct investment on employment generation in Nigeria from 1990 to 2010 using the Ordinary Least Square (OLS) statistical method. Also utilized was the Engel and Granger time series approach. Variables of the model include total employment growth rate in Nigeria, Export growth rate, Import growth rate, Exchange rate, Inflation rate and Foreign Direct Investment. The findings of the study showed the existence of significant link between FDI flows and employment in Nigeria both in the shortrun and long run. Furthermore, external factors such as real effective exchange rate, import rate and internal factors like inflation and export rates were important factors in explaining employment rate in Nigeria.

Dromel, Kolakez and Lehmann (2010) investigated the impact of the credit market development on the level and persistence of unemployment using a panel data of 19 OECD countries from 1982 to 2003. The study employed the Generalised Least Square (GLS) estimation technique. The findings of the study revealed a negative relationship between persistence of unemployment and financial sector development.

Shabbir, Anwar, Hussain and Iman (2012) examined the contribution of financial sector development in the reduction of unemployment rate in Pakistan from 1973 to 2007. The study utilized the ARDL statistical technique and found that increases in the activities of the financial sector have positive significant impact on the reduction of unemployment in Pakistan both in the short run and long run. It was further observed that credit extension to the private sector engenders job opportunities and increases the level of employment in Pakistan.

Emmanuel, Abiola and Anthony (2015) studied the impact of private sector credit on economic growth in Nigeria. The Error Correction Model (ECM) confirmed a positive and statistically significant effect of private sector credit on output. The variables employed included the Real Gross Domestic Product (RGDP) as the dependent variable, deposit money banks' credit to private sector (CPSG), government expenditures, exchange rate, liquidity ratios as monetary policies respectively.

Paul, Chibueze and Callistus (2016), in a bid to ascertain whether porfolio investment affect employment growth in Nigeria, using single equation, reduced form specification, and employing data for the period 1980 to 2014 , found that in the long term, portfolio investment impacts employment growth positively and significantly. This outcome supports the general view in the literature of a positive relationship between portfolio investment 
and economic growth, and calls attention to this variable which has hardly been considered in employment generation constructs on account of its famed volatility and risk.

Abaukaka (2014) examined the relationship between foreign direct investment and employment generation in Nigeria using multiple linear regression model for data which covers the period from 2002 to 2012 . To empirically establish the relationship, some variables were incorporated into the econometric model which included Employment level as the dependent variable while the explanatory variables were FDI (percentage of nominal value of FDI in Nbn), GDP (annual GDP growth rate) and the nominal interest rate. From the empirical results, FDI exhibited negative relationship with the level of employment in Nigeria while GDP, interest rate was positively related with the level of employment but non of the explanatory variables significantly impacted on the level of employment in Nigeria within the period of the study. Also the value of $\mathrm{R}^{2}$ and as well as F-statistic reveals that all variables in the model did not significantly impact on the level of employment in Nigeria. The researcher was therefore of the view that the negative relationship of FDI with employment level calls for critical examination because if FDI has been established by many findings of researchers to have positive impact on GDP, it is expected that it should equally bring about reduction in the level of unemployment. At this, the paper recommended amongst others that government should put in place mechanism whereby the research institutions go in partnership with major industries in the country to develop skills that are adaptable in the contemporary job market and government should ensure that the needed infrastructural facilities are provided to attract more investors.

Hamidah, Rosfadzimi, Abu, Abd Halim and Noorazilah (2016) examined the impact of FDI on employment rate in Malaysia. Other factors such as the number of foreign workers, gross domestic product (GDP) and exchange rate (EXCR) were also included in the study. Data used in the study was annual data spanning from 1980 to 2012. Autoregressive distributed lag (ARDL) model was used to determine the long run relationship between the variables. The study found that FDI, number of foreign workers, and GDP significantly influenced the unemployment rate in Malaysia.

Malik and Saima (2013) studied the impact of foreign direct investment on employment level in Pakistan. Data time span was 1970-2011. The variables in the study were employment level, foreign direct investment, exchange rate and GDP per capita. The study used Johanson Co-integration approach to analyze the long run relationship between the dependent and independent variables. The result showed the existence of long run relationship.

Akram (2016) studied the impact of foreign direct investments (FDI) on both the unemployment rate and economic growth in Jordan using empirical analysis of the times series data from 1998-2015. The ordinary least squares (OLS) method was used to explore the relations and the impact of FDI on both of the unemployment and real GDP. The result of the analysis showed that one percentage increase in FDI causes a decrease of $(0.009 \%)$ of the unemployment rate in Jordan during the study period and in the meantime resulted in an increase of $1.219 \%$ of real Gross Domestic Products (GDP).

Pavlos and Nikolaos (2014) investigated the relationship between unemployment rate, FDI and economic growth in Greece using annual time series data for the period 1970-2012. Several econometric models were employed including the bounds testing (ARDL) approach and ECM ARDL model. The results confirmed a longrun relationship among the examined variables. The VECM granger causality results indicated both in the shortrun and long-run, a strong unidirectional causality between economic development and FDI with direction from economic development to FDI.

\subsection{Methodology}

The quasi-experimental research design which allows the evaluation of the effect of independent variables on the dependent variable was adopted in this study. The design was adopted because it sought to explore the impact of the proxies of private sector investments on unemployment rate in Nigeria.

The data for this work were collected from secondary sources. The data were obtained from the Central Bank of Nigeria Statistical Bulletin and World Bank Development Indicators published by World Bank from the period 1986 to 2016. These data contained information regarding the components of private sector investments (such as Private Domestic Investment, Foreign Direct Investment, and Foreign Portfolio Investment) as well as Unemployment rate in Nigeria.

The researcher used the Johansen co-integration test to test for long-run relationship between the variables. To investigate the short run dynamics between the variables when the variables in the model are co-integrated, the Vector Error Correction Mechanism (VECM) and least squares system equation were equally employed. In other words, the VECM was used to correct the short term-analysis of co-integration test, if the short term analysis shows the existence of a spurious regression.

\section{Model Specification}

Model specification enables empirical exploration of economic phenomenon which is strictly guided by theoretical consideration. The relationship between the dependent variable $\mathrm{Y}$ and a set of $\mathrm{k}$ independent variables $\mathrm{x}_{1}, \mathrm{x}_{2} \ldots \ldots \mathrm{x}_{\mathrm{n}}$ 
can be expressed as:

$\mathrm{Y}_{\mathrm{t}}=\mathrm{b}_{\mathrm{o}}+\mathrm{b}_{1} \mathrm{x}_{1}+\mathrm{b}_{2} \mathrm{x}_{2} \ldots \ldots+\mathrm{b}_{\mathrm{n}} \mathrm{x}_{\mathrm{n}}+$

Where:

$\mathrm{Y}=$ dependent variable

$\mathrm{b}_{\mathrm{o}}=$ the intercept

$b_{1} \ldots \ldots b_{n}=$ slope or the parameters of the model to be estimated.

The model for this research is modeled as shown below:

$\mathrm{UNR}=\mathrm{f}$ (PDI, FDI, FPI) .3

The above functional relationship in its estimated form becomes:

$\mathrm{UNR}=\alpha_{0}+\alpha_{1} \mathrm{PDI}_{\mathrm{t}}+\alpha_{2} \mathrm{FDI}_{\mathrm{t}}+\alpha_{3} \mathrm{FPI}_{\mathrm{t}}+\mathrm{e}_{\mathrm{t}}$ 4

Where:

UNR = Unemployment Rate

PDI = Private Domestic Investment

FDI $=$ Foreign Direct Investments

FPI $=$ Foreign Portfolio Investment

$\mathrm{t}=$ time $\mathrm{t}$

$\alpha_{1-} \alpha_{3}=$ Parameters to be estimated or slope

$\alpha_{0}=$ Intercept.

\subsection{Analysis and Results}

Table 4.1: Data set on Unemployment Rate, Private Sector Investments - Private Domestic Investments, Foreign Direct Investments and Foreign Portfolio Investments (1986-2016)

\begin{tabular}{rrrrr} 
& \multicolumn{1}{c}{ UNR } & \multicolumn{1}{c}{ PDI } & \multicolumn{1}{l}{ FDI } & \multicolumn{1}{l}{ FPI } \\
YEAR & \multicolumn{1}{c}{ rate $(\%)$} & \multicolumn{1}{c}{$\mathrm{Nb}$} & \multicolumn{1}{l}{$\mathrm{Nb}$} & \multicolumn{1}{l}{$\mathrm{Nb}$} \\
1986 & 5.3 & 0.01135 & \multicolumn{1}{c}{0.7358} & \multicolumn{1}{l}{0.1516} \\
1987 & 7 & 0.01523 & 2.4528 & 4.3531 \\
1988 & 5.1 & 0.01756 & 1.7182 & 2.6118 \\
1989 & 4.5 & 0.02683 & 13.8774 & -1.6188 \\
1990 & 3.5 & 0.04012 & 4.686 & -0.4352 \\
1991 & 3.1 & 0.04519 & 69.161 & -0.5949 \\
1992 & 3.5 & 0.07081 & 14.4631 & 36.8518 \\
1993 & 3.4 & 0.09692 & 29.6603 & -0.377 \\
1994 & 3.2 & 105.58 & 22.2 & -0.2 \\
1995 & 1.9 & 141.92 & 75.9 & 5.8 \\
1996 & 2.8 & 204.05 & 113.3 & -12.1 \\
1997 & 3.4 & 242.9 & 110.5 & -4.8 \\
1998 & 3.5 & 242.26 & 80.7 & -0.6 \\
1999 & 17.5 & 231.66 & 92.8 & 1 \\
2000 & 13.1 & 331.06 & 116 & 51.1 \\
2001 & 13.6 & 372.14 & 132.4 & 92.5 \\
2002 & 12.6 & 499.68 & 225.2 & 24.8 \\
2003 & 14.8 & 865.88 & 258.4 & 23.6 \\
2004 & 13.4 & 863.07 & 248.2 & 23.5 \\
2005 & 11.9 & 804.4 & 654.2 & 116 \\
2006 & 12.3 & 1546.53 & 624.5 & 360.3 \\
2007 & 12.7 & 1936.96 & 759.4 & 332.5 \\
2008 & 14.9 & 2053.01 & 971.5 & 157.2 \\
2009 & 19.7 & 3050.58 & 1273.8 & 70.9 \\
2010 & 5.1 & 9183.059 & 905.7 & 566.6 \\
2011 & 6 & 8425.762 & 1360.3 & 792.4 \\
2012 & 10.6 & 8640.765 & 113.5 & 2687.2 \\
2013 & 10 & 9320.347 & 875.1 & 2130.2 \\
2014 & 6.4 & 10571.74 & 738.2 & 832.4 \\
2015 & 10.4 & 10432.23 & 602.1 & 498.1 \\
2016 & 13.9 & 3345.578 & 1124.1 & 477
\end{tabular}

Sources: (1) World Bank Development Indicators Published by World Bank, 2016

(2) Central Bank of Nigeria Statistical Bulletin, 2016 


\section{Unit Root}

This test was carried out in order to determine the level of integration (stationarity) of the variables used in the study. This was carried out in order to avoid spurious relationship since most time series data are not stationary. This test was conducted with the aid of the Augmented Dickey Fuller (ADF) unit root test. The summary of the result is as shown below (see appendix B for the detailed e-views unit root for each of the variable in the model).

Table 4.2 Augmented Dickey Fuller Unit Root Test Results

\begin{tabular}{|c|c|c|c|c|c|}
\hline Variable & $\begin{array}{c}\text { ADF t-statistic at 1 } \\
\text { difference }\end{array}$ & \multicolumn{3}{|c|}{ Mackinnon critical values } & $\begin{array}{c}\text { Order of } \\
\text { integration } \\
\text { I (d) }\end{array}$ \\
\hline UNR & -6.729174 & -3.679322 & -2.967767 & -2.622989 & I (1) \\
\hline PDI & -3.151527 & -3.679322 & -2.967767 & -2.622989 & I (1) \\
\hline FDI & -10.84952 & -3.679322 & -2.967767 & $-\mathbf{2 . 6 2 2 9 8 9}$ & I (1) \\
\hline FPI & -4.683693 & -3.679322 & -2.967767 & $-\mathbf{2 . 6 2 2 9 8 9}$ & I (1) \\
\hline
\end{tabular}

Source: e.views 9.0 output.

The table above revealed that the ADF statistic values in absolute terms were greater than the mackinnon critical values at $1 \%, 5 \%$ and $10 \%$ levels at first order difference. In other words, the variables are integrated at order I (I) thus, qualifies the model for co-integration analysis to determine the existence of long-run relationship of the variables.

\section{Long Run Relationship}

In order to establish existence of long-run relationship, the variables were subjected to the Johansen co-integration test as show below:

Table 4.3 Johansen co-integration test.

Date: 12/11/17 Time: 09:45

Sample (adjusted): 19882016

Included observations: 29 after adjustments

Trend assumption: Linear deterministic trend

Series: UMP1 FDI1 FPI1 PDI1

Lags interval (in first differences): 1 to 1

Unrestricted Cointegration Rank Test (Trace)

\begin{tabular}{ccccc}
\hline \hline $\begin{array}{c}\text { Hypothesized } \\
\text { No. of CE }(\mathrm{s})\end{array}$ & Eigenvalue & $\begin{array}{c}\text { Trace } \\
\text { Statistic }\end{array}$ & $\begin{array}{c}0.05 \\
\text { Critical Value }\end{array}$ & Prob.** $^{* *}$ \\
\hline \hline None $*$ & 0.944982 & 141.4759 & 47.85613 & 0.0000 \\
At most 1 & 0.798751 & 57.37287 & 29.79707 & 0.0000 \\
At most 2 & 0.312794 & 10.87967 & 15.49471 & 0.2190 \\
At most 3 & $3.95 \mathrm{E}-05$ & 0.001145 & 3.841466 & 0.9724 \\
\hline \hline
\end{tabular}

Trace test indicates 2 cointegrating eqn(s) at the 0.05 level

* denotes rejection of the hypothesis at the 0.05 level

**MacKinnon-Haug-Michelis (1999) p-values

Unrestricted Cointegration Rank Test (Maximum Eigenvalue)

\begin{tabular}{|c|c|c|c|c|}
\hline $\begin{array}{l}\text { Hypothesized } \\
\text { No. of CE(s) }\end{array}$ & Eigenvalue & $\begin{array}{c}\text { Max-Eigen } \\
\text { Statistic }\end{array}$ & $\begin{array}{l}0.05 \\
\text { Critical Value }\end{array}$ & Prob.** \\
\hline None * & 0.944982 & 84.10300 & 27.58434 & 0.0000 \\
\hline At most $1 *$ & 0.798751 & 46.49319 & 21.13162 & 0.0000 \\
\hline At most 2 & 0.312794 & 10.87853 & 14.26460 & 0.1604 \\
\hline At most 3 & $3.95 \mathrm{E}-05$ & 0.001145 & 3.841466 & 0.9724 \\
\hline
\end{tabular}

Max-eigenvalue test indicates 2 cointegrating eqn(s) at the 0.05 level

* denotes rejection of the hypothesis at the 0.05 level

**MacKinnon-Haug-Michelis (1999) p-values

\section{Source : e-views 9.0 Output}

TheJohansen co-integration test reported in table 4.3 above revealed that the null hypothesis of no co- 
integration was rejected. Both the trace statistic and the maximum eigenvalue results showed two (2) co-integrating equation at $5 \%$ level of significance. Thus, we conclude that there is the existence of long-run relationship between the independent variables and dependent variable.

Nevertheless, there is no doubt that deviations from this relationship could emerge as result of changes in any of the variables in the short-run. Therefore, the Error Correction Mechanism (ECM) was employed to determine the speed of adjustment in the long-run having established co-integration.

\section{Vector Error Correction Mechanism}

The Vector Error Correction Estimates (See Appendix D) for unemployment rate is appropriately signed with a negative coefficient of -0.006644 and a t-statistic of -0.33935 . This implies that about approximately $0.66 \%$ of disequilibrium in the long-run is corrected every year by changes in private sector investment. To ascertain the significance of the t-statistic and establish causality between the endogenous and exogenous variables, the system equation for unemployment rate was extracted using the ordinary least square (OLS) analysis.

\section{Long-Run Causality}

Table 4.4 Dependent Variable: D(UMP1)

Method: Least Squares (Gauss-Newton / Marquardt steps)

Date: 12/11/17 Time: 09:48

Sample (adjusted): 19882016

Included observations: 29 after adjustments

$$
\begin{gathered}
\mathrm{D}(\mathrm{UMP} 1)=\mathrm{C}(1) *(\mathrm{UMP} 1(-1)-44.0591781562 * \mathrm{FPI} 1(-1)+37.9119396263 \\
\text { *PDI1(-1) - 0.189740760631) + C(2)*( FDI1 }(-1)+3.4826598637 * \mathrm{FPI} 1( \\
-1)-3.97935487832 * \mathrm{PDI} 1(-1)+0.0591895334724)+\mathrm{C}(3) * \mathrm{D}(\mathrm{UMP} 1( \\
-1))+\mathrm{C}(4) * \mathrm{D}(\mathrm{FDI} 1(-1))+\mathrm{C}(5) * \mathrm{D}(\mathrm{FPI} 1(-1))+\mathrm{C}(6) * \mathrm{D}(\mathrm{PDI} 1(-1))+\mathrm{C}(7)
\end{gathered}
$$

\begin{tabular}{|c|c|c|c|c|}
\hline & Coefficient & Std. Error & t-Statistic & Prob. \\
\hline $\mathrm{C}(1)$ & -0.006644 & 0.019578 & -0.339354 & 0.7376 \\
\hline $\mathrm{C}(2)$ & -0.179151 & 0.259970 & -0.689123 & 0.4980 \\
\hline $\mathrm{C}(3)$ & -0.529828 & 0.245670 & -2.156662 & 0.0422 \\
\hline $\mathrm{C}(4)$ & -0.195994 & 0.402299 & -0.487184 & 0.6309 \\
\hline$C(5)$ & 0.032671 & 0.369093 & 0.088518 & 0.9303 \\
\hline$C(6)$ & -1.481848 & 0.692516 & -2.139802 & 0.0437 \\
\hline $\mathrm{C}(7)$ & 0.220010 & 0.173248 & 1.269913 & 0.2174 \\
\hline R-squared & 0.279704 & Mean dependent var & & 0.046670 \\
\hline Adjusted R-squared & 0.083259 & S.D. dependent var & & 0.859110 \\
\hline S.E. of regression & 0.822569 & Akaike info criterion & & 2.653736 \\
\hline Sum squared resid & 14.88562 & Schwarz criterion & & 2.983773 \\
\hline Log likelihood & -31.47917 & Hannan-Quinn criter. & & 2.757099 \\
\hline F-statistic & 1.423832 & Durbin-Watson stat & & 1.982520 \\
\hline Prob(F-statistic) & 0.250209 & & & \\
\hline
\end{tabular}

\section{Source : e-views 9.0 Output}

The Unemployment rate system equation information provided in the above table showed that the $t$-statistic probability value of 0.7376 was insignificant. Therefore, causality cannot be concluded or established in the long run. In other words, private sector investment do not significantly granger cause unemployment in the long run. However, in the short run, it was observed that past unemployment rate lagged one period and private domestic investment also lagged one period has significant but negative relationship on unemployment rate in Nigeria as shown in the system equation above. 
Granger Causality Estimate

Table 4.5 Pairwise Granger Causality Tests

Date: 12/11/17 Time: 09:49

Sample: 19862016

Lags: 2

\begin{tabular}{lccr}
\hline \hline Null Hypothesis: & Obs & F-Statistic & Prob. \\
\hline \hline FDI1 does not Granger Cause UMP1 & 29 & 0.17751 & 0.8384 \\
UMP1 does not Granger Cause FDI1 & & 3.55738 & 0.0444 \\
\hline \hline FPI1 does not Granger Cause UMP1 & \multirow{2}{*}{29} & 0.05035 & 0.9510 \\
UMP1 does not Granger Cause FPI1 & & 0.00556 & 0.9945 \\
\hline \hline PDI1 does not Granger Cause UMP1 & 29 & 1.40913 & 0.2639 \\
UMP1 does not Granger Cause PDI1 & & 1.44580 & 0.2553
\end{tabular}

Source: e-views 9.0 output

The pairwise granger causality results showed that there was no bi-directional relationship between the variables under consideration rather a uni-directional causality was observed between unemployment rate and Foreign Direct Investment. That is to say, unemployment rate granger causes FDI.

\section{Interpretation of Results}

This study was carried out to examine the impact and nature of relationship between private sector investments and unemployment rate in Nigeria. It made effort to empirically investigate the influence of the compositions of private sector investments (private domestic investment, foreign direct investment and foreign portfolio investments) on unemployment rate in Nigeria from 1986 to 2016.

The time series data used for analysis were subjected to unit toot analysis so as to determine their levels of stationarity. The unit root test result carried out with aid of the Augmented Dickey Fuller unit root analysis revealed that the variables were co-integrated at order 1(1) or first difference. Thus, qualified the estimate for cointegration analysis to determine the existence of long run relationship between private sector investment and unemployment rate in Nigeria. The Johansen co-integration estimate results confirmed that at $5 \%$ level of significance, both the trace statistics and the maximum eigen value showed two cointegrating equation thereby establishing the existence of long run relationship between the independent variables and the dependent variable. To determine the speed of adjustment, short run dynamics or disequilibrium in the long run due to changes in private sector investments, the Vector Error Correction Mechanism or Model (ECM) was employed. The result revealed that the ECM was properly signed with negative coefficient of -0.006644 and a t-statistic of -0.33935 , which implied that about approximately $0.66 \%$ of disequilibrium in the long-run would be corrected every year by changes in private sector investment. The system equation result estimate to establish the significance of the tstatistic, confirmed that the t-statistic is insignificant given a probability value of 0.7376 which is greater than $5 \%$. Thus, causality cannot be concluded between private sector investments and unemployment in Nigeria in the long run. The insignificant impact of private sector investments in addressing unemployment issues could be attributed to population growth which may be high and above the level of employment created by the private sector. As the population grows, the labour force also grows and not always commensurate with the number of retirements at a given period in time. However, a significant but negative short-run relationship was found between past unemployment rate, private domestic investment lagged one period and unemployment rate in Nigeria.

Furthermore, causality result indicated there was no bi-directional relationship between private sector investment and unemployment rate in Nigeria. This implies, that the former do not granger cause unemployment rate. But there exists a uni-directional relationship or causality running from unemployment rate to foreign direct investment, which could be as a result of cheap labour in the country due to high level of unemployment rate. This study therefore agrees with the work of Dromel, Kolakez and Lehmann (2010), Haruna, Saifullahi and Mukhtar (2013), Akram (2016), Malik and Saimu (2013) and Vasile, Adriana and Andreea (2015) who found a long run relationship between private sector investments and the absence of causality among the variables respectively. On the other hand, the work did not agree with the work of Shabbir, Anwar, Hussain and Imam (2012) who found positive significant impact of private sector investment on unemployment rate in Pakistan.

\subsection{Summary, Conclusion and Recommendations Summary and Conclusion}

The study has been able to provide empirical information on the nature of relationship between private sector investments and unemployment rate in Nigeria. Private Domestic Investment, Foreign Direct Investment and 
Foreign Portfolio Investment were the proxies for private sector investment and the unemployment rate used as a proxy or measure of unemployment rate. According to economic and financial literatures, It is a truism that private sector investments granger causes unemployment rate. Based on the analyses and results of the Johansen cointegration test, Error Correction Mechanism and Ordinary Least Square System Equation, there exist a long run relationship between private sector investments and unemployment rate in Nigeria though the effect of private of sector investment was not significant to confirm causality. Further examination revealed the existence of negative relationship and short-run impact of past unemployment rate and private domestic investment lagged one period and unemployment rate. Another striking revelation made by the study is that cheap labour due to high level of unemployment rate granger causes foreign direct investment.

\section{Recommendations}

The following recommendations are made based on the findings of this study.

1. Sustainable policies that will ensure and encourage growth of private sector investments should be vigorously pursued by stakeholders in the industry. These policies could come in form of access to cheap funds (through reduced interest rates or cost of funds), subsidization of inputs in the production process and tax waivers for newly established firms among other policy initiatives. This is especially for private domestic investment which has shown to have a significant effect in the reduction of unemployment rate in Nigeria.

2. There is no gain saying the fact that population growth also affects the level of significance/impact private sector investments have on unemployment level. To this end, government and its agency should fashion out ways of putting the population growth on check through education and health care programmes in the areas of family planning, re-orientation to counter some obnoxious belief that leads to upsurge in population growth especially in the rural areas, affordable health care system, seminars, talk-shows etc.

3. Tax credit or tax waivers should be given to private sectors that employ more or reasonable number of the workforce as a way of encouraging the sector. This can help in creating more jobs and reduce the unemployment rate.

4. The government and its agencies should ensure adequate provision of infrastructural development like good roads, electricity etc. These encourage private sector investment growth, create employments and thus engender reduction in the unemployment rate.

\section{References}

Abaukaka T. O. (2014) Foreign Direct Investments and Employment Generation Nexus in Nigeria. Journal of Educational and Social Research MCSER Publishing, Vol. 4 No.5 Pp 119-128

Ademu, W. A. (2006) The informal sector and employment generation in Nigeria; The role of Credit. NES 2006 Annual Conference.

Agbadu, A (2007) Nigeria and Foreign Investors. Business Times. Nov. 14 Pp 9.

Akram M. H. (2016) Analysis of Foreign Direct Investment and Unemployment and Their Impact on Economic Growth in Jordan. International Journal of Investment Management and Financial Innovations 2016; 2(1): $1-12$

Aminu, M. F. and Mustapha A. Z (2014) Private Sector and Youth Employment Generation in Nigeria: A Review. International Journal of Business \& Law Research 2(3) Pp 45

Bahar B (2003) The Role of private Sector Investments in the Economic Performance of OIC Member Countries. Journal of Economic Cooperation, 24 (1) Pp. 63-110

Clem N and AlajekwuUdoka B (2016) Effect of Private Sector Investment on Economic Growth in Nigeria. $N G$ Journal of Social Development Vol. 5. No. 4. Aug. Pp 150-167

CBN, (2015): Central Bank of Nigeria. Statistical Bulletin: retrieved from www.cenbank.org.

Dromel, N.L., Kolakez, E. and Lehmann E (2010) Credit Constraints and Persistence of Unemployment. Labour Economics No. 17 Pp 823-834.

Elsby M., Hobijn B., and Sahin A. (2013) Unemployment Dynamics in the OECD Review of Economics and Statistics. Vol, 95, No. 2

Emmanuel, O.O, Abiola, O.A. and Anthony O. U (2015) Impact of Private Sector Credit on Economic Growth in Nigeria. CBN Journal of Applied Statistics . Vol. 6 No. 2 Dec. Pp. 81-101

Ernst E and Rani U (2011) Understanding the Unemployment Flows" Oxford Review of Economic Policy Making Vol. 27. No. 2

Hamidah M, Rosfadzimi M, Abu H. S. M, AbdHalim M. and Noorazilah I. (2016) Impact of Foreign Direct Investment on the Unemployment Rate in Malaysia. Journal of Physics: Conference Series. Pp 1-10

Haruna, M.A, Saifullahi, S. I and Mukhtar S (2013) An Empirical Investigation Into The Relationship Between Financial Sector Development and Unemployment in Nigeria. Asian Economic and Financial Review. 3 (10) 
Pp 1361-1370

ICLS (2013) Resolution Concerning Statistics of Work Employment and Labour Underutilization, 19 International Conference of Labour Statisticians, Geneva, http://www.ilo.org/global/statistics.

ILO (1982) international Labour Organization Resolution Concerning Statistics of the Economically Active Population, Employment, Unemployment and Underemployment.

Imoisi, A. I, Abuo, M and Sogules, I W (2015) Domestic Investment and Economic Growth in Nigeria from 19702-13: An Econometric Analysis. Canadian Social Science. Vol. 11 No. 6 Pp 70-79.

Khan, M. and Reinhart C. (1990) Private Investment and Economic Growth in Developing Countries. World Development Vol. 18

Malik D. H. and Saima S. (2013) Impact of Foreign Direct Investment on Employment Level In Pakistan: A Time Series Analysis. Journal of Law, Policy and Globalization. Vol.10, 2013 Pp 46-55

National Bureau of Statistics (2011). Annual Socio-Economic Report

National Bureau of Statistics (2106) Annual Socio Economic Report. Universal Resource Location.

Oni, T.o, Imolehin, O. A, Adelowo, W.B and Adejumo, A. V.(2014) Foreign Private Investment and Economic Growth in Nigeria (1980-2010). International Journal and Economic Sustainability. Vol. 2. No. 1 Pp 39-48 Mar.

Paul E, Chibueze Aand Callistus O (2016) Does Foreign Portfolio Investment Affect Employment Growth in Nigeria? Journal of Economics and Sustainable Development Vol.7, No.12, Pp 81-84

Pavlos, S and Nikolaos D (2014) The Impact of FDI on the Unemployment rate \& Economic Growth in Greece: A time Series Analysis. International Work-Conference on Time Series Analysis Pp 97-108.

Salami, A. O. and Oyewale, I. O. (2013) Impact of Foreign Direct Investment on Employment Generation in Nigeria. International Journal of Economic Development Research and Investment. Vol. 4. No. 1. Pp 64-75

Shabbir, G., Anwar, S., Hussain, Z. and Iman, M. (2012) Contribution of Financial Sector Development in Reducing Unemployment in Pakistan. International Journal of Economics and Finance, 4(1). Pp260-268

Soludo, C (1998) Investment in the Growth Process: A Measure of the Economists Ignorance In Africa in Udo ed: Determinants of Private Investment in Nigeria: An Empirical Exploration. Journal of Economics and Sustainable Development. Vol.7, No.11, 2016 Pp 80

Tony E. (2016) How the Private Sector Can Help Economic Development. Universal Resource Location

Udo N. E (2016) Determinants of Private Investment in Nigeria: An Empirical Exploration. Journal of Economics and Sustainable Development. Vol.7, No.11, 2016 Pp 80

World Bank (2017) World Development Indicators (WDI), February, 2017) 